\title{
A Course Design Guideline for Legal English Teaching in Chinese Tertiary Education: From the Perspective of Content-based Instruction
}

\author{
$\mathrm{Xia} \mathrm{Yu}$ \\ Foreign Language School, Southwest University of Political Science and Law, China \\ Yunshu Xiao \\ Foreign Language School, Southwest University of Political Science and Law, China
}

\begin{abstract}
Although the course of English for Specific Purposes (ESP) is increasingly popular in China, ESP courses today are no more than teaching specific words and phrases and translating texts following the traditional grammar-translation method. With China's active participation in the international affairs, more importance is expected to be attached to the design of ESP courses that can be facilitative in preparing learners for their future career in an international context. Under such circumstance, this paper is intended to offer a layout principle of ESP course design tailored for Chinese university law students based on Content-based instruction (CBI) approach. It first reviews conceptual notions regarding CBI and then move to look into related issues concerning the current ESP course design. Admittedly, these issues can be viewed from differential angles in diverse ESP contexts, the proposed framework for ESP course design is expected to be beneficial to teachers who are engaged in ESP course development.
\end{abstract}

Index Terms — content-based instruction, English for specific purpose, course design, legal English

\section{INTRODUCTION}

As the globalization of trade and economy intensifies, English for Specific Purposes (afterwards ESP) is enjoying more popularity the world over. Although ESP courses are gaining more attention in China and many institutions and universities start to run a variety of ESP courses for seniors, the instruction, unfortunately, is no more than teaching specialized lexicon and sentence structures. This pedagogical approach which typically follows traditional grammar-translation method, according to Gao (2007), essentially ignores the learners' academic pursuit and personal interests or needs. This inevitably results in low motivation in their English learning and, in turn, substandard performance in their future profession when they have to communicate in English in their particular field.

Thus, university English faculties are facing the task of equipping the students for an extremely competitive society in which those who are both steeped in their specific area and proficient in their professional communication can stand out. That is to say, English teachers are expected to design up-to-the-standard English courses that can help learners best prepare for their professional communications in the near future.

Based on a Content-based approach, this paper is to propose a sample ESP course design for law students which serves as a guideline for legal English teaching in China at tertiary level. As a point of departure for my discussion, I shall have a brief conceptual review of Content-based instruction (afterwards CBI) and backdrop information for Legal English course.

\section{CONCEPTUAL Review OF CONTENT-Based InSTRUCTION}

Content-based instruction (afterwards CBI) is a significant pedagogical approach in language education. It has generally been understood as an integrated approach with dual focus on language skills and content mastery. Language and content, according to Mohan (1986), should be learned at the same time. This point of view puts an emphasis on the significance of language and content integration.

Based on Mohan's framework, the ESP literature over the past decades has been seen numerous interpretations or definitions of CBI. Brinton et al. (1989), for example, has defined CBI as the 'integration of particular content with language-teaching aims', while content refers to 'regular subject matter that students are currently learning such as mathematics, geography, and history, etc'. (cited in Du, 2009)

Surely the difference between CBI and other language approaches lies not only in what to teach but also in how to teach. For example, the grammar-translation approach emphasizes the significance of raising the students' consciousness to linguistic rules in language teaching. Communicative language teaching emphasizes interaction as both the means to and the ultimate goal of learning a language. Advocates of CBI believe that the involvement of relevant subject matter knowledge may motivate the students to be more actively engaged in language activities and 
thus develop the relevant skills (Du, 2011).

In summary, within literature there exist a wide range of differing conceptions vis-a-vis the nature and scope of CBI. However, it is generally agreed that the integrative approach provides a meaningful basis for language teaching and speeds up the process of L2 mainstream success (Williams, 1995). According to Krashen (1987), "sheltered subject-matter teaching," which he calls SSMT (and we are calling CBI), is the most effective way to teach a foreign language. As a matter of fact, the development of CBI in "immersion" bilingual programs and in programs for English as a Second Language have had a significant impact on CBI in foreign language education (see Stryker \& Leaver, 1997 for details).

Quite obviously, CBI supports contextualized learning. That is to say, learners are taught useful language that is embedded within relevant discourse contexts rather than as isolated language fragments. Hence students make greater connections with the language and what they already know. Another important factor underlying content-based instruction is keeping students motivated and interested. The fundamental philosophy here is that when students are motivated and interested in the material they are learning, they make greater connections between topics, elaborations with learning material and can recall information better. In short, when a student is intrinsically motivated, the student achieves more. This in turn leads to a perception of success, of gaining positive attributes which will continue a circular learning pattern of success and interest. (cf. Wikipedia)

\section{BACKGROUND INFORMATION OF THE LEGAL ENGLISH COURSE}

Although the importance of English as an international language is well recognized by the central government (Boyle, 2000) and English has been included in the curriculum as a compulsory subject for four consecutive terms in tertiary education, English is not the medium of subject instruction for college students in China. Chinese is the medium of instruction of all subject matter at the vast majority of colleges and universities with the exception of a small number of elite universities. Consequently, expertise and English have been in a status of split or separation. This directly leads to the dilemma of distortions in supply and demand in the job market. Take the legal profession as an example, professionals in law with high English proficiency are badly needed in foreign legal firms and legal affairs department in international company. But in contrast to this, many a law student having B.A or even M.A and Certificate of CET (College English Test) Band 6 are incapable of taking up related responsibilities due to the lack of professional training on Legal English. In response to the gap between what the job-seeker has to offer and what the employer requires, many colleges and universities offer a variety of ESP courses for their students to enhance the chance of employment and enable them to participate more fully in an increasingly complex academic and social environment.

At Southwest University of Political Science and $\operatorname{Law}^{1}$ (afterwards SWUPL) in China where the current course design is to be conducted, law is the most important subject and most students are to work in the judicial field upon their graduation. Law courses offered by SWUPL include civil law, administrative law, economic law, criminal law, international law, criminal investigation, legal litigation and basic legal theories. A required undergraduate course in Legal English is offered for part of law students in the fourth term.

The purpose of the course is to enhance the students' English skills in legal contexts so as to prepare them for successful participation in their future professional communication. After three semesters' study in their specific legal area and general college English, we assume that students have a proficient understanding of law-related subjects and their English proficiency is sufficient to deal with the Legal English course. Obviously, it is high time for law students to start an ESP course which is tailored for their future professional or academic ${ }^{2}$ needs.

\section{ENGlish For Legal Purpose Course}

\section{A. An Overview}

The Legal English course is designed for law students at university who are obviously pre-experience learners. The legal English course normally runs parallel to law courses so that students can associate their subject knowledge they have learned with the legal English context whenever relevant. Since the Legal English course is among compulsory subjects, the students' performance is evaluated at the end of the semester. It focuses broadly on the four basic language skills of listening, reading, writing and speaking because it is unrealistic for the students to predict which specific skill their future jobs require (Gao, 2007).

To use coursebooks in university class is a general practice in China, the course teacher, however, has freedom to choose supplementary materials for the students, especially in an ESP course. Therefore, the teaching resources used in Legal English class are usually one coursebook plus some extra complementary materials selected by the course teacher. For example, related legal articles and original legal documents are often chosen for reading comprehension.

Normally, authentic materials are chosen as teaching resources because the target students' English proficiency is

\footnotetext{
${ }^{1}$ As one of the oldest political science and law universities in China, Southwest University of Political Science and Law (SWUPL) was accredited as a key university by the State Council in 1978. She became the first key university in Chongqing co-administrated by Ministry of Education and Chongqing Municipality.

2 This course is aiming at preparing the students for an optional course of more advanced Legal English set for seniors and for their graduate study if they choose to further their education.
} 
assumed to be sufficiently adequate, at least for the current course. In the case of SWUPL, the Legal English course is exclusively offered to advanced classes ${ }^{3}$. Nearly all students passed College English Test Band 4 (afterwards CET 4 ) and most of them even passed College English Test Band 6 (afterwards CET 6). All the reading texts or learning materials are selected from original legal books and journals or foreign affair-related legal documents. Although these materials are not written for English teaching purposes, the contents are interesting and meaningful for the learners because of their relevance to the subject matter they are learning or have learned in law courses.

\section{B. Needs Analysis}

According to Brindley (1989, p. 65), needs "do not have of themselves an objective reality", rather, "what is finally established as a 'need' is a matter of agreement and judgment not discovery (Lawson, 1979, p. 37). The needs established for a particular group of students will be an outcome of a needs analysis project and the perspective of the definition of needs. In this paper, the goal-oriented definition of needs (Widdowson, 1981, p. 2) is adopted to refer to students' study or job requirements, that is, what they have to be able to do at the end of their language course.

In order to conduct a reliable needs analysis, 'a triangulation of questionnaires, informal discussions with learners and other lecturers, interviews with ex-students and lecturers, and observation of former students' actual workplace experiences is conducted before the course' (Gao, 2007). Learner performance and assignments are appraised during the course and tests results are analyzed after the course. This amalgamation of pre-course, mid-course and post-course analyses helps the course teacher understand what the students are like at the start, middle and end of the course. The combined feedback then serves to inform the course teacher as to how the next round of course should be revamped or revised.

\section{Rationale}

Questionnaires are one of the most common research tools. It is economic in terms of time required and provides easier ways to collect and analyze data than many other means of research (cf. Babbie, 1998; Bryman, 2001; Dornyei, 2003). It is advisable that the pilot questionnaire be administered to present and past students and to lecturers (see Lonnfors, 1978 for an example of piloting questionnaires).

As for interview, the current course teacher can get information about the learners' English proficiency, their particular weak points and what they need to learn and improve upon through this course through interviewing the lecturers who taught the College English course in the previous year. These interviews or discussions can be carried out individually or in groups if possible, in an informal manner. Informal discussion can provide a relaxing atmosphere in which students are well encouraged to express their ideas and thoughts openly and the interviewers are allowed to change questions or the way of phrasing questions as well as asking follow-up questions to probe into further information. It is desirable, however, for the interviewer to adopt a "structured interview" where, in effect, the interviewee is guided by the interviewer through a questionnaire. Besides, interviewing the ex-students with carefully designed questions can be another effectual way of collecting data. And to observe those ex-students in their working places can also be informative because they probably have the best say of whether the ESP course has prepared them effectively or not.

Assessing learners' performances and assignments during the course can be helpful to know their real problems or difficulties during this course. After analyzing the feedback, fine-tuned readjustment to the following course could be invaluable for both teachers and learners. In addition, a mid-term test and final-term examination are also indispensable to check their progress and to ascertain what they already know as well as what they do not know (cf. Hutchison \& Waters, 1987; Robinson, 1991).

As already mentioned, students have already had command of specific subject knowledge upon entering the course. For the first three academic terms at the university, they are required to take College English course and most of them have passed the CET 6. This legal English course is a bridge between their subject matter and their foreign language skills to further enhance their English expertise in authentic legal communication context.

\section{GUIDELINE FOR LEGAL ENGLISH COURSE IN SWUPL}

\section{A. Goals and Objectives}

In the broad sense, the fundamental goal of legal English teaching is to enhance the balanced development of the learners' subject knowledge and English proficiency, enable them to become active in thinking and broad in vision, and ultimately, have a positive impact on the learners' employment prospect (H. Zhang, 2011). Therefore, the overall objective of the course is to help the law students prepare for their future profession because good command of their expertise coupled with high level of English proficiency can give them an edge in today's competitive job market. In general practice, the students send out their resumes to companies in order to seek interview opportunities before recruitment, as a result, job application constitutes an indispensable part of the course. In their future legal career, they

\footnotetext{
${ }^{3}$ The students registering at the university were divided into two levels in terms of English proficiency at the end of the first academic year: while only one tenth of the students in each school were singled out to be placed in an advanced class, the remaining ones were grouped into low and intermediate classes.
} 
might be working in a law firm or an international company or institution where English is employed as a working language when they communicate with other colleagues or customers from all over the world.

Goals

Law students are expected to become familiar with legal terminology and write adeptly in English by the end of the course. They should, for instance, be able to write simple legal documents, e-mails as well as a resume of high quality. Moreover, they should be capable of understanding intermediate legal articles and documents, conducting common professional conversation orally and maintaining relationships with the international community in their specific area through such modern means of communication as e-mail and MSN or Skype.

Objectives

The objectives for each skill are stated in Table 1:

TABLE 1

OBJECTIVES OF THE COURSE

\begin{tabular}{|ll|}
\hline Skills & objectives \\
\hline Listening: & To understand conversations in legal communication settings. \\
Speaking: & To communicate effectively with native/non-native English speakers in job interviews and legal communication settings. \\
Reading: & To understand various texts, such as legal monograph, reports, documents and journal articles. \\
Writing: & To write resumes and law-related letters or e-mails. \\
\hline
\end{tabular}

\section{B. Outline of the Course}

The course lasts one academic semester, a duration of 17 weeks. The total length of the course is 51 hours $(3$ academic hours a day; 1 day a week). The number of students in each class is usually between forty and fifty. The target learners are sophomore undergraduates (at their second term) from the law-related schools ${ }^{4}$ and resources of the course comprise a textbook set by the school authority and in-house materials and visuals selected by the ESP teacher.

The course covers four language areas/skills_-listening, writing, speaking and reading in which the following are taught (see Table 2):

TABLE 2

OUTLINE OF THE COURSE

\begin{tabular}{ll|} 
Skills & Contents to be taught \\
\hline Listening: & Interactions/exchanges at the court; conversations with legal contacts; job interview; legal news. \\
Speaking: & Introductions; job interview; conversations in international legal contexts. \\
Reading: & Legal documents; journal articles; case reports; monographs (for elite students). \\
Writing: & Resume; cover letters; legal letters/documents; e-mails; notes; memos. \\
\hline
\end{tabular}

As mentioned earlier in the paper, the overall English level of the law students is comparably sufficient enough to cope with the legal English course. Therefore, the authentic materials are thought to be appropriate in terms of difficulties in language and content although they may find some vocabulary alien to them. "Authentic materials" refers to the use of print, audio, video and pictorial material originally produced for a purpose other than the teaching of language (Robinson, 1991). The subject content is not a problem for this cohort of students because, as already mentioned, they possess sufficient background knowledge of law in their specific areas taught in Chinese.

\section{Needs Analysis}

According to Hutchison \& Waters (1987), what distinguishes ESP from General English is not the existence of a need as such but rather an awareness of the need. As I see it, it is not so much the awareness of the need which distinguishes the ESP from general course but rather the implementation of learners' needs throughout the ESP course. A combined analysis of pre-course, mid-course and post-course performances serves to get sufficient information about what students have learned and what they still need to learn and improve through this course. The following (Table 3) shows the structure of the needs analysis:

TABLE 3

THE STRUCTURE OF THE NEEDS ANALYSIS

\begin{tabular}{|ll|}
\hline Stages of Needs Analysis & Tools used for Needs Analysis \\
Pre-course Needs Analysis: & Questionnaires, Interviews, Informal Discussions \\
Mid-course Needs Analysis: & Results of learners' daily performance and assignments, Mid-term Test \\
& Results, Observation \\
Post-course Needs Analysis: & Final Test Results, Checklists, Informal discussions/interviews \\
\hline
\end{tabular}

\section{Course Evaluation}

A basic distinction is made between formative and summative evaluation (Robinson, 1991, p. 65). Formative evaluation is carried out during the life of a course or project and the results obtained can be used to modify what is

\footnotetext{
${ }^{4}$ They are School of administrative law, School of civil and commercial law, School of criminal law, School of economic and trade law and School of international law.
} 
being done. Summative evaluation, on the other hand, is carried out when the course or project is finished and when it is clearly too late to any 'fine tuning', at least in this round of course. Two types of evaluation are to be implemented in the current course. They are to be reflected in the following procedures:

\section{Observation}

According to Robinson (1991), observing past students who are working may be an effective means in seeing to what extent the ESP course has fully prepared them for workplace needs. In addition, classroom observation is also essential to 'furnish the evaluator with assumed important process variables that characterize the work in the classroom' (Mackay, 1981, p. 115). Such observation should be able to inform the course designer who then readjusts the course materials and/or teaching methods for the next year students.

Mid-course and end-of-course evaluation

According to Feez (1998), a mid-course evaluation questionnaire can be given to learners in order to fine-tune the course before it finishes. End-of-course evaluation is normally achieved through analyzing learners' final examination results and performance. This kind of course evaluation helps to assess whether the course objectives are being met whether the course, in other words, is doing what it was designed to do. If the outcome consistently shows that the course fails to meet the course objective, then something must be wrong with the course design: the objective may be too ambitious given the resources available; the analysis of the learners' initial competence may be wrong; the methodology adopted in the course may be inappropriate (Hutchison \& Waters, 1987).

Questionnaire, checklist and interviews

Many a expert has written about the construction and design of questionnaire and some of the problems involved when questionnaire is used as a technique of evaluating ESP course (see, e.g., Mackay, 1981; Smith, 1989). Needless to say, feedback from questionnaires drawn up for students, ex-students, ESP teachers and subject specialists can be very informative. However, we should not be oblivious of the obvious problems with using questionnaire as a way of ESP course evaluation which may include the length, possible misinterpretation of questions by respondents and failure of respondents to return them. A checklist is much shorter than a questionnaire and can be used when the evaluation is focused on small-scale aspects of a course program, for example, one component of a syllabus. The questions in a checklist may be closed (Yes/No/Don't know), which are easiest for computer check or analysis. Face-to-face interviews are time consuming, but provide the opportunity for more extended exploration of the points than do questionnaires or checklists. Ideally, the interviews are planned and structured; that is, the same or related questions are asked of each interviewee (Robinson, 1991).

Self-assessment and achievement assessment

Brindley (1989, p. 1) suggests the involvement of the learners themselves in the process of assessment. Self-assessment can be implemented through the following: oral production (student self-checklist; peer checklist; listening to tape-recorded oral production to detect pronunciation or grammar mistakes); self-revision and listening comprehension (cf. Brown, 2001). Achievement assessment is usually internal to the course and reflects the nature and content of the course itself (Alderson \& Hughes, 1981). The achievement test can be used to examine whether or to want extent learners have learned what has been taught. One way of building in some cross-checking of results is by triangulation, that is, by targeting the same point by means of two or more techniques of evaluation, for instance, seeking information on one aspect by means of observation, interview and achievement test.

\section{CONCLUSION}

This paper has reviewed conceptual notions regarding CBI and then discussed some core issues in ESP course design on the basis of previous empirical studies (see, e.g., Feng, 2008; Wang, 2009; W. Zhang, 2002). The initial step in ESP course design is analyzing learners' particular needs, to be specific, what the learner has to know (necessities), the gap between what the learner knows already and what they need to know (lacks), and what the learners view as to what their needs are (wants) (cf. Hutchison \& Waters, 1987; Hutchison, Waters, \& Breen, 1979). Only based on learners' needs and their target language proficiency can the teacher determine goals and objectives of the course, a process which involves consideration of specific functions, terminology comprehension, and the abilities required for future workplace communication (Gao, 2007). Finally, assessment and evaluation also constitute an indispensable part in the course design. It helps the course teacher to examine the extent to which the course objectives are met. By way of exemplifying, the paper puts forward a proposal for an ESP course design targeted to law students in SWUPL. It is hoped that this paper will offer heuristics for other course designers devoted to developing ESP courses in similar contexts and will serve as springboard onto more substantive research than has been hitherto attempted.

\section{REFERENCES}

[1] Alderson, J. C., \& Hughes, A. (Eds.). (1981). ELT Documents III: Issues in Language Testing. London: British Council.

[2] Babbie, E. (1998). The Practice of Social Research. Belmont, CA: Wadsworth.

[3] Boyle, J. (2000). A brief history of English language teaching in China. IATEFL, 15(5), 68-79.

[4] Brindley, G. P. (1989). The role of needs analysis in adult ESL programme design. In R. K. Johnson (Ed.), The Second Language Curriculum. Cambridge: Cambridge University Press.

[5] Brinton, D. M., Snow, M. A., \& Wesche, M. B. (1989). Content-based second language instruction. New York: Newbury 
House.

[6] Brown, H. D. (2001). Teaching by Principles: An Interactive Approach to Language Pedagogy. New York: Longman.

[7] Bryman, A. (2001). Social Research Methods. Oxford: Oxford University Press.

[8] Dornyei, Z. (2003). Questionnaires in Second Language Research: Construction, Administration and Processing. London: Lawrence Erlbaum Associates, Inc.

[9] Du, J. (2009). Content and language integration in tertiary education in China: A case study in Wuhan Law College. The Asian ESP Journal, 5(1), 61-77.

[10] Du, J. (2011). Content-Based Instruction. Wuhan: Huazhong University Press.

[11] Feez, S. (1998). Text-based Syllabus Design. Sydney: National Centre for English Language Teaching and Research, Macquarie University.

[12] Feng, G. (2008). English film and Legal English teaching. Literature in Film (8), 105-106.

[13] Gao, J. (2007). Designing an ESP course for Chinese University Students of Business. The Asian ESP Journal, 3(1), 97-106.

[14] Hutchison, T., \& Waters, A. (1987). English for Specific Purpose. Cambridge: Cambridge University Press.

[15] Hutchison, T., Waters, A., \& Breen, M. P. (1979). An English language curriculum for technical students. Unpublished manuscript, Lancaster.

[16] Krashen, S. D. (1987). Principles and Practice in Second Language Acquisition. Englewood Cliffs, New Jersey: Prentice-Hall International.

[17] Lawson, K. H. (1979). Philosophical Concepts and Values in Adult Education. Milton Keynes: Open University Press.

[18] Lonnfors, P. (1978). Needs analysis project for the lay person. Paper presented at the the 6th Europeam Symposium on LSP.

[19] Mackay, R. (1981). Accountability in ESP programmes. ESP Journal, 1(2), 107-121.

[20] Mohan, B. (1986). Language and content. Reading: Addison-Wesley Publishing Company.

[21] Robinson, P. C. (1991). ESP TODAY: A Practitioner's Guide. Hemel Hempstead: Prentice Hall International (UK) Ltd.

[22] Smith, S. (1989). On using questionnaires for in-company course evaluation. Language Training, 10(2).

[23] Stryker, S. B., \& Leaver, B. L. (Eds.). (1997). Content-Based Instruction in Foreign Language Education: Models and Methods. Washington, DC: Georgetown University Press.

[24] Wang, L. (2009). The application of case study in Legal English teaching. Youth Science, (12), 185-186.

[25] Widdowson, H. G. (1981). English for specific purpose: Criteria for course design. In L. Selinker, E. Tarone \& V. Hanzeli (Eds.), English for Academic and Technical Language: From practice to principle (pp. 1-11). Oxford: Pergamon Press.

[26] Wikipedia. (17 March 2013). Content-based instruction. Retrieved March 27, 2013, from http://en.wikipedia.org/wiki/Content-based_instruction.

[27] Williams, A. (1995). Content-based language teaching: Problems and promise. La Trobe University, La Trobe.

[28] Zhang, H. (2011). The features of Legel English teaching and its challenges. Chinese Journal of ESP, 2(1), 15-21.

[29] Zhang, W. (2002). Legal English and foreign affairs lawyer: Effective Legal English teaching. Journal of Xi'an International Srudies University (2), 84-87.

Xia Yu received her $\mathrm{PhD}$ at the University of Southampton, UK and is currently employed as Senior Lecturer at Foreign Language School, Southwest University of Political Science and Law, People's Republic of China. Her research interests include educational linguistics, second language acquisition and English for Specific Purposes. She has published a number of studies in her areas of expertise, which have appeared in scholarly publications in China, Oceania, Europe and North America.

Yunshu Xiao is currently a professor at Foreign Language School, Southwest University of Political Science and Law, People's Republic of China. He is the vice-chairman of the Chinese Association of Legal Linguistics and serves in many other academic positions. 